\title{
Simulation, Control and Desire: Urban Commons and Semi-Public Space Resilience in the Age of Augmented Transductive Territorial Production
}

\author{
Manfredo Manfredini \\ University of Auckland, School of Architecture and Planning, New Zealand \\ m.manfredini@auckland.ac.nz
}

\begin{abstract}
Considering place-based participation a crucial factor for the development of sustainable and resilient cities in the post-digital turn age, this paper addresses the socio-spatial implications of the recent transformation of relationality networks. To understand the drivers of spatial claims emerged in conditions of digitally augmented spectacle and simulation, it focuses on changes occurring in key nodes of central urban public and semi-public spaces of rapidly developing cities. Firstly, it proposes a theoretical framework for the analysis of problems related to socio-spatial fragmentation, polarisation and segregation of urban commons subject to external control. Secondly, it discusses opportunities and criticalities emerging from a representational paradox depending on the ambivalence in the play of desire found in digitally augmented semi-public spaces. The discussion is structured to shed light on specific socio-spatial relational practices that counteract the dissipation of the "common worlds" caused by sustained processes of urban gentrification and homogenisation. The theoretical framework is developed from a comparative critical urbanism approach inspired by the right to the city and the right to difference, and elaborates on the discourse on sustainable development that informs the New Urban Agenda. The analysis focuses on how digitally augmented geographies reintroduce practices of participation and commoning that reassemble fragmented relational infrastructures and recombine translocal social, cultural and material elements. Empirical studies on the production of advanced simulative and transductive spatialities in places of enhanced consumption found in Auckland, New Zealand, ground the discussion. These provide evidence of the extent to which the agency of the augmented territorialisation forces reconstitutes inclusive and participatory systems of relationality. The concluding notes, speculating on the emancipatory potential found in these social laboratories, are a call for a radical redefinition of the approach to the problem of the urban commons. Such a change would improve the capacity of urbanism disciplines to adequately engage with the digital turn and efficaciously contribute to a maximally different spatial production that enhances and strengthens democracy and pluralism in the public sphere.
\end{abstract}

Keywords: semi-public space, transductive spatialities, urban commons

To cite this article:

Manfredini, M. (2019), Simulation, Control and Desire: Urban Commons and Semi-Public Space Resilience in the Age of Augmented Transductive Territorial Production. The Journal of Public Space, 4(2), I79-198, DOI 10.3289|/jps.v4i2. 1209

This article has been double blind peer reviewed and accepted for publication in The Journal of Public Space.

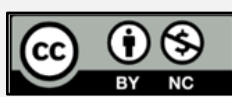
This work is licensed under a Creative Commons Attribution - Non Commercial 4.0 International License https://creativecommons.org/licenses/by-nc/4.0/ 


\section{Appraising the complexity of contemporary urban commons}

As part of the "world in common," inclusionary urban commons are key civic institutions -crucially also including public space - for the affirmation of the collective dimension of the city and its development as a just, safe, healthy, accessible, affordable and resilient place (Borch \& Kornberger, 2015; Flusty, 1997; Garnett, 2012). As such, these commons are a universally accessible part of the common non-commodifiable asset, whose conception, construction, management and usage are expression of open, collective and pluralistic associations. The domain of their free and participatory networks comprehends four main areas: a) production, consumption, and safeguarding of public services and goods; b) relationality communication, interaction, and encounter; c) culture and creativity; and, most important, d) politics and citizenship. Problems affecting the world in common have been central in the modern discourse on urbanisation (Hardt \& Negri, 2009; Harvey, 20I I, 2012; Hodkinson, 2012; Lee \& Webster, 2006; Lefebvre, 1996; Parr, 2015; Purcell, 2002; Stanek, 20II; Susser \& Tonnelat, 20I3) and have recently been addressed by the New Urban Agenda (20I6), the highest level document including global principles, policies and standards for urban development. Among the streams on relations between space and political spheres, and critical changes in urban society, a leading area has concentrated on the public realm and the critique of the decay of the public condition with the crisis of public interactions and expressions (McQuire, 2008; Sennett, 1977, 2008). Causes linked to the expansion of private power and control systems have been discussed with fundamental references to the work of Hannah Arendt (1958), who focused on the occlusion of the political sphere towards plurality of human difference; Jurgen Habermas, who examined societal contradictions of the modern "feudalisation" of the public sphere in relation to the negation of citizenship rights (Calhoun, 1992); and Nancy Fraser (1993), whose discourse on the multiplicity of publics and the publicness of some private elements addressed emerging issues of inequality and relationality, segmentation and subordination. Critical stances on these issues have consolidated and become robust particularly around issues of spatial control (Dehaene \& De Cauter, 2008a; Foucault 1995; Harvey, 2003), socio-economic polarisation processes concerning privatisation (Dawson, 2010; Lee \& Webster, 2006; Low, 2006; Minton, 2012; Soja, 20I0); spatial justice (Low \& Smith 2006; Mitchell, 2003); socio-spatial segmentation (Dawson, 2010; Harvey, 2003; Hodkinson, 20I2); consumption and alienation (Debord, 1983; Firat \& Venkatesh, 1995; Miles \& Miles, 2004); and selective deprivation of public space (Davis, 1990; Harvey, 2003; Mitchell, 1995, 2003; Sorkin, 1992). In the production of public realm, the penetration of the private sector affects all levels of conception, delivery, and governance, and progressively expands globally. Recent decades have seen its very acute diffusion in contexts of rapid urbanisation both in Asia and Australasia, starting from the decolonising territories, such as Hong Kong, Singapore, Australia and New Zealand, to massively propagate in the growing economies of largest East and Southeast Asian countries, such as China and Indonesia.

For the appraisal of the growing complexity of this phenomenon, a comparative urbanism approach is adopted here to address the way regional differences produce specific countering forces and organisations that strengthen the resiliency of local communities and their capacity to protect the commons. This approach can critically analyse the complexity of these antagonist forces in their contexts and systematically 
understand similarities and differences among different processes to contribute to the development of the discourse on such a rapidly evolving matter. By establishing an intimate relation between theoretical work and empirical practice, it is not only possible to align the nature of the research practice to that of the studied phenomenon, but, importantly, to entirely appreciate the contribution to theory of particular phenomena emerging in urban laboratories, such as the Chinese Special Administrative Zones, that present non-generalisable power relations. This approach uses a mixed methodology that both disentangles and maintains the associated, complex and concurrent aspects of each process spatial production: the conceived, lived and represented dimensions. This investigation is framed by and bridges major research traditions in critical urbanism: firstly the work on space of Henry Lefebvre (1991 [1974], 1996, 2003 [1970], 2004 [1992]; Goonewardena, Kipfer, Milgrom \& Schmid, 2008; Purcell 2002, 20I4; Soja 1998, $2000)$; secondly Richard Sennett's $(1977,2008,2018)$ idea of the open city; and lastly territorial research related to actor-network and assemblage theories (Anderson \& McFarlane 201 I; Deleuze \& Guattari 1987, 2000; Farías \& Bender, 2010; Latour 1999, 2005; Law, 2009; McFarlane 20I I; Murdoch 1998). A specific development of ANT, territoriological studies, provides important support to address the "unpredictable multiplication, interpenetration and ongoing production" (Brighenti, 20I4: 2) of territories that characterise the commons of our age (Brighenti, 20I4: 3 and passim; Kärrholm, 2012; Merriman, 20I2).

Territorial behaviour studies help to understand the spatial production of enduring networks where plasticity has become a fundamental characteristic. They provide instruments to unravel individual practices as well as complex associational processes within specific translocalised, distributed and diffused systems where nodes (people and things), bodies (stabilised sub-associations of nodes) and sorts (stabilised patterns composed of variable nodes) establish a large variety of open, mobile, migrating and non-linear configurational dynamics over space and time. The concentration on strategies of occupation, tactics of appropriation, and effects of association of sociospatial constitutive processes progressively expands from individual acts and actors into multidimensional assemblages of practices and apparatuses with heterochronic relations. The analysis of practices and apparatuses elicits the irreducible specificity of each actor - or to use Bruno Latour's (1999: 303; 2005: 7I) terminology, actant - in its physical (devices, materials and objects), social (routines, bonds, alliances and conflicts) and semantic (languages, signs and representations) aspects. The actants are also explored in their permanent involvement in loops of establishing and re-establishing "chains of activation and reactivity" (Brighenti, 20I4: 20) through processes that are either routine or ad hoc, confined and translocal, and tangible and intangible. The chains are addressed to evaluate their effectiveness and efficaciousness in shaping, organising and transforming the public socio-spatial systems of the city. Each peculiar form, dynamic and effect generated by situated aggregations of associative systems is seen as an expression of chains of relations reflecting the fundamental tension between territorial grounding and relational responsiveness (Massey, 2007).

Particularly relevant in the background of this discussion on spatialisations of relational systems is the contention of the ontogenetic capacity of urban space and the correlative citizens' right to the city (Harvey, 2008; Lefebvre, 1996; Park, 1967) that concern historically specific material, and conceptual and quotidian practices of appropriation, 
association and control (Lefebvre, 199I [1947]). This tenet has been recently adopted by the New Urban Agenda (2016), advocating for a pluralist and inclusive public sphere that constitutes an effective antidote to the progressive fragmentation of the social, cultural and environmental body of the city. Plurality, freedom, and autonomy of thought and action are seen as indispensable to an exercise of this right that enables the establishment of emancipatory and equitable spatialities of integral relationality (Villa, 1992). Imbued in it, is the Arendtian idea of a democratic agonistic pluralism that sustains equitable participation in social dialogue and exchange of our increasing cosmopolitan conditions, acknowledging conflict as essential elements of the political in a complex civil society (Mouffe, 1999, 2008).

Recognising difference as irreducible and non-substitutable value of pluralism, this framework provides theoretical instruments to detect and evaluate the growth and appearance of concrete instances of spatialised practices that set free diversifying forces to overcome divisions, repetitions and confinement and enable us to maintain centrality in "make and remake ourselves and our cities" (Harvey, 2008: 23). Differentiation, a process whose maximal expression ensures the exercise of collective power over the processes of urbanisation and socialisation, is therefore identified as a fundamental "right." The right to difference (Lefebvre, 1987: 396) protects the citizen against the attempt of hegemonic economic groups to expand their dominating power with processes of abstraction that normalise and homogenise diversity. Yet, maximal differentiation is not an external force, but develops within and in antagonism to abstractive domains. It internally opposes the deceptive stratagems of abstract space that, by implementing "technology, applied sciences, and knowledge bound to power" to cast sameness ("induced diversity") as multiplicity, "fetishize space" and make "the milieu of the commodity... become a commodity", to progressively "set itself up as the space of power" (Lefebvre, 199I [1974]: 50-5I). This capacity of differentiation to emerge from its most adverse conditions is confirmed by a paradox identified by Foucault (200I) in an interview where he stated that "at that very moment it became apparent that if one governed too much, one did not govern at all - that one provoked results contrary to those one desired" (352).

The author's previous studies on differential coutermovements emerged within local manifestations of abstractive globalising state or corporate apparatuses have shown how relevant forces for the reconstitution of urban integrity can grow from spatialised practices ("I do not think that there is anything that is functionally - by its very nature absolutely liberating. Liberty is a practice" [Foucault, 2005: 354]) virtual-spatial assemblages transversally diffused through societal strata. The metamorphic, loose constitution, plural potentiality and self-organisation of micropolitics and creative becoming of these tangible forces generated "insurgent citizenship" forms that incrementally instituted themselves as major stabilised associations. Their production had various origins, ranging from the political activism of such actors as members of the networked transnational movement that emerged (Figure I) in the Istanbul's Gezi park protest (Manfredini, Zamani, \& Leardini, 2017), to the accomplices behaviour of those who constituted the participatory post-consumerist communities of the major New Zealand malled metropolitan centre (Manfredini, 2019). Importantly, these forces have a dual dynamic. On one hand they grew through resonance machinic processes (Connolly, 2005) that feed on the antagonist mechanisms of deception sympathetically mirroring 
them into liberating qualitative assemblages of "unconnected or loosely associated elements [that] fold, bend, blend, emulsify, and dissolve into each other" (p. 870). On the other hand, their persistence relies on their capacity to match the ever-widening power - also granted by disenfranchisement or unaware complicity of citizens - of hegemonic forces of the post-civil (Dehaene \& De Cauter, 2008a) and meta-consumerist society (Miles, 2010) in enhancing their systems of spatio-behavioural control to identify, homogenise and fragment their antagonist "seeds." In other words, these forces must constantly resonate with their opponents to identify and counter the steadily shifting abstraction tactics of concealment of multiple radical contradictions and imperfect alliances, such as the ones that inform the pseudo-civic commodified commons of their negated constituencies (e.g., the proposed Taxim's mosque or the privately owned, branded Town Squares of Auckland's malls).

Research on the contribution to society of this insurgent citizenship has highlighted its important agency in reverting the unequal and unjust commodification of goods and services necessary to secure physical, social and cultural wellbeing (Banerjee 200 I; Fuller, Hickey \& Bunnell, 2012; Holston, 2009; Manfredini \& Jenner, 2015; Manfredini, Xin, Jenner, \& Besgen, 2017; Minton, 2012; Soja 2010; Susilo \& De Meulder, 2018). It has a demonstrated capacity to contribute to establishing common grounds for multiple and often contradictory and conflicting parties, where they can democratically compete for the affirmation of their ideas and values, guaranteeing the establishment of positive space-based ontogenetic processes that directly and permanently involve the participation of all stakeholders, and foster inclusion, autonomy and social interplay. It triggers concurrent actions to associate networks and institute mechanisms of territorial production that establish open, anti-hierarchical and participatory relational systems.

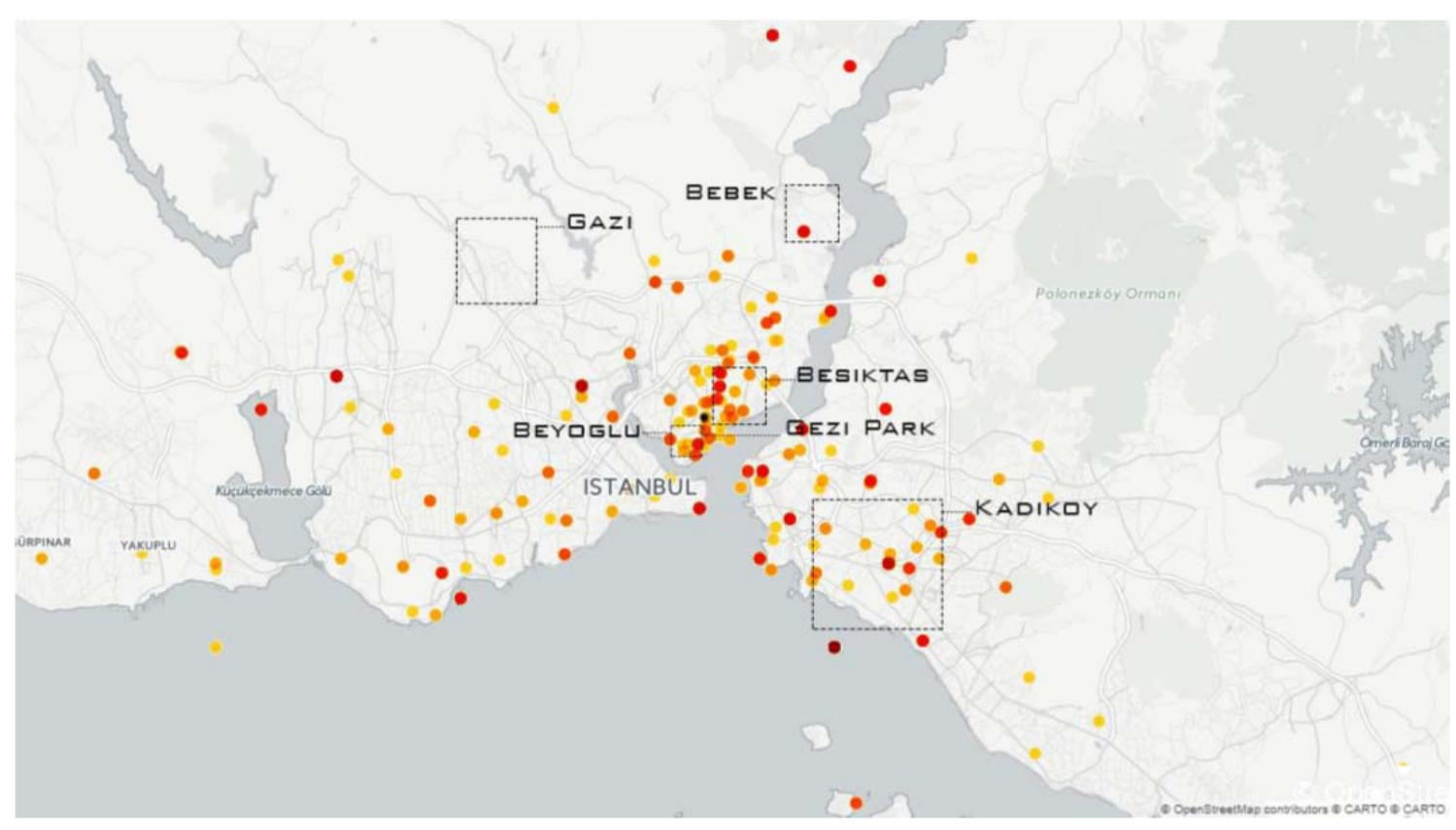

Figure I. Map of the distribution of tweets (the darker the colour the intense the activity) during the Gezi Park Movement (February-March 2013) all the geotagged tweets mentioning pro-Gezi hashtags. Courtesy F. Zamani. 

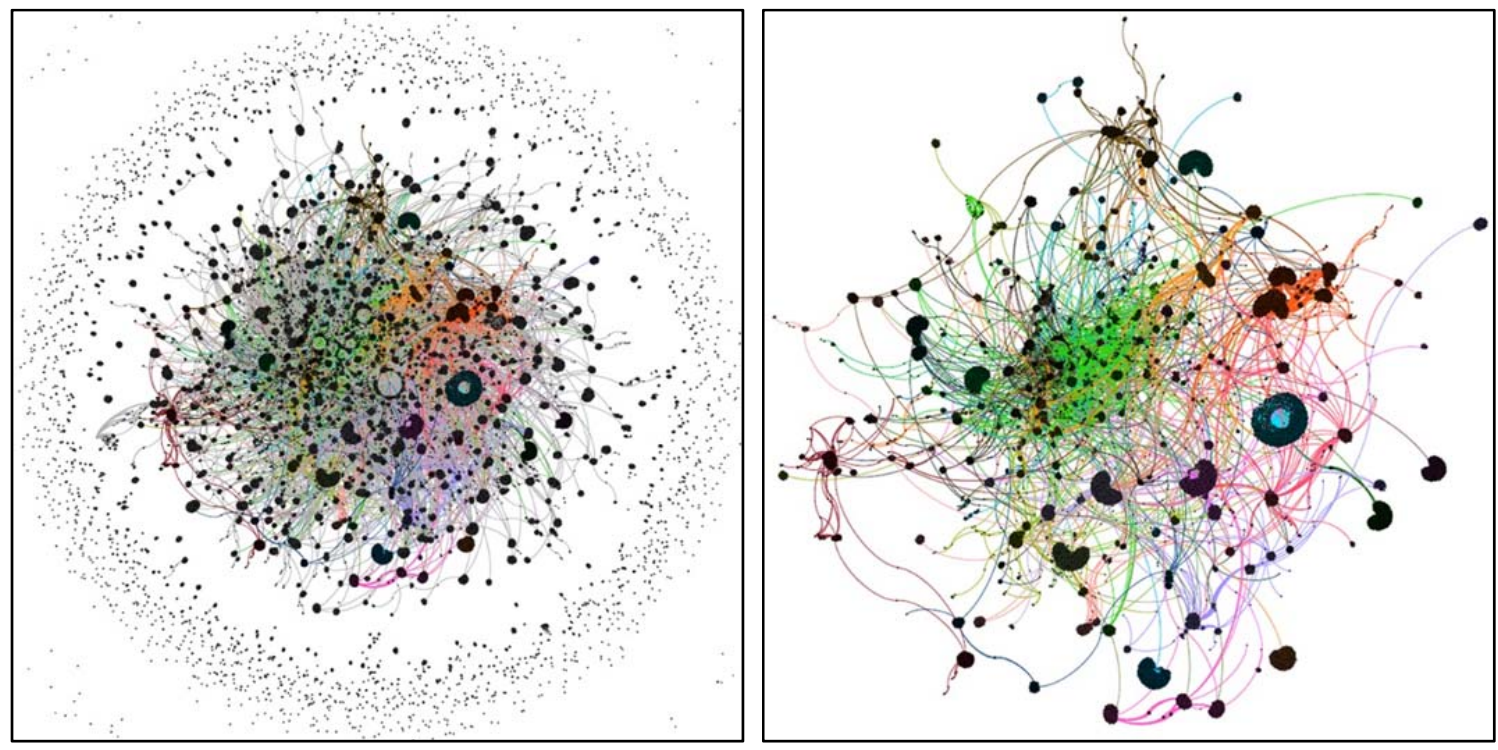

Figure 2. Digital network charts of Sylvia Park Metropolitan Centre, Auckland, in 2017 (I/I-3 ///2) using Instagram data - comments only - showing all (left) and the larger (right) communities (more than $1 \%$ of total interactions) in the main POI.
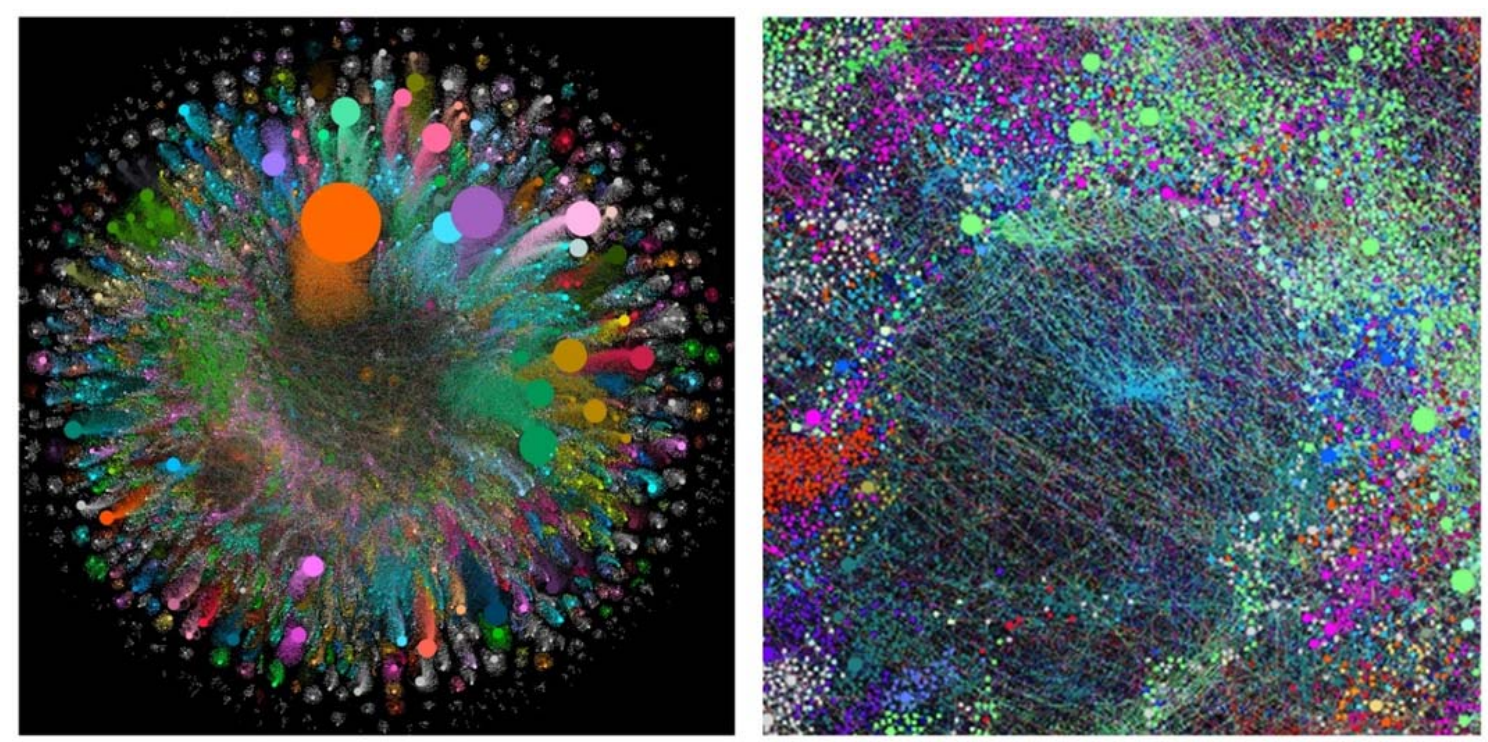

Figure 3. Network analysis - all interactions - showing all communities (left) and a detail (right) (more than $1 \%$ of total interactions) in the main POI of Instagram in Sylvia Park Metropolitan Centre in 2017.

\section{Urban commons production and urban restructuring issues}

Problems affecting the traditional commons are directly related to growing sustainability issues of progressive process of socio-spatial fragmentation and deterritorialisation in urban society. The neoliberal governance model, implemented in most global legal jurisdictions in recent years, has overridden the political hindrances to the affirmation of an enhanced version of the original liberalism, and brought about a strong delegation of state responsibilities, promotion of the free exercise of individual self-interest, and 
increased support to capital accumulation (Brenner \& Theodore, 2005; Harvey, 2003; Parr, 2015; N. Smith, 2002). Aiming to deliver social good through a market-driven approach it has trusted the capacity of the market to offset inequalities by enhancing economic growth. A consequent reduction in both direct and indirect state intervention has led to the implementation of free forms of regulation that transfer to or share with other than the public sector responsibility for providing services to the population. Fiscal limitations faced by local governments have led to important divestment in the existing public urban infrastructure and profound restructuring of public assets and deployment of resources. Existing commons have been subjected to an increasing difficulty in the delivery of services. The private sector has promptly seen new opportunities for capital reproduction. Commons and their operations have been colonised, transformed or displaced, and assimilated into market resources (Bollier, 2002).

The new meta-commons have attracted much criticism for the "failure of individualized private property rights to fulfil common interests in the way they are supposed to do" (Harvey, 2012: 75). Various mechanisms of property and/or governance transfer have been developed and implemented for public space. New initiatives, such as business improvement districts, have shown limited institutional legitimacy and minimal prevention of the creeping privatisation that generates disparities within local communities (Garnett, 2012: 2020; Steel \& Symes, 2005: 332). The underlying economisation of community wellbeing has degraded the traditional unnegotiable primacy of social responsibility in safeguarding and promoting the quality of people's "common world" (Hardt, 20 I0; Hardt \& Negri, 2009). The diminished public control and negotiating power of the state over the effectiveness and efficaciousness of the civil infrastructure has further facilitated urban gentrification processes and the related social polarisation issues. This has manifested [in] the inhibition of the spontaneous unfolding of political possibilities, and genuine forms of relationality, participation, collaboration, encounter and exchange.

The penetration of hegemonic private organisations in the key nodes of the relational infrastructure has often brought about deterritorialisations of consolidated spatial systems on social, cultural and temporal axes. The following reterritorialisations, established to financially capitalise on "local advantage" (Harvey, 20I2), have implied the transfer of territorial control of strategic parts of civic life centres to the private sector and exposed their socio-spatial bodies to irreparable damages. The dispossession and displacement of civic commons from their communities have disrupted their physical networks, planning capacity and everyday life. A striking example of displacing effects was found by the main author, during a study on the radical transformation the People's Park district in central Guangzhou, China in 201 I. Interviews with two displaced members of a residential settlement under demolition were effectuated in the only remaining alley of the quarter. The former residents, approached whilst wandering in a vain search for their former neighbours, treasured and shared their memories triggered by the smallest material evidence linked to their missed decades-long daily practices that no "mod cons" could have ever replaced.

The extent of socio-spatial alienation produced by these processes is related to the entity of the "rationalisation," restructuring and consolidation procedures introduced with the new conception and management models. It can seamlessly affect all scales, 
from macroscopic to microscopic, ranging from the formation of large exclusionary urban enclosures to the introduction of an individual building's regulations that exclude access by "undesirables," such as anti-social youth and the homeless (Doherty et al., 2008).

These reterritorialisations often include strategies that economise local cultural advantage and cast the relationships between local communities and places into vulgarised representations. Several creative city-led urban redevelopments, renewals and re-imaging programmes have included the staging and simulation of authentic elements and disrupted the relational chains that can guarantee a sustainable development and preserve a sense of belonging and identity of places (Mommaas, 2004; Shepherd, 2002; Zukin, 1991). The survival of isolated fragments of both tangible and intangible historical networks and institutions that support the physical, social and cognitive-spatial dimensions of locales is often conducive to their complete dismissal. This not only affects the local communities that have shaped themselves and their spatialities over time, but also the wider society that shares "not only with those who live with us, but also with those who were here before and those who will come after us" (Arendt, 1958: 55; Benhabib, 2000) what it has in common through the network of consolidated relational assemblages

This replacement of common worlds with users' alienated semi-public enclosures also brings about problems of suspension of democratic accountability. Research shows the critical effects on communicative acting of exclusionary, censorship, surveillance practices enacted in privately governed urban places (Atkinson, 2003; Loukaitou-Sideris, 1993; Minton, 2012). The deprivation of possibility to participate in open processes of publicly relevant urban spaces creates "strangely 'placeless' places, cut off from their original wellsprings of local life and vitality" (Minton, 20I2: 4), undermining trust, citizenship and democracy. In places like shopping malls, the deprivation that affects basic rights is deliberately exercised and explicitly stated in regulations or codes of conduct. The ban on any activity purposely disturbing the public peace, or interfering with the flow of visitors, and other behavioural limitations often include the negation of freedom regarding to assemble and congregate in groups of three or more; wear apparel that disguises, obscures or conceals the face; and engage in expressive activities not sponsored by the governing organisations. Some privately owned public spaces, such as the "excess plot ratio" networks of corridors, halls, plazas and flyovers of Hong Kong, usually have publicly approved regulations allowing their governing bodies to "cleanse" social space, with actions such as excluding "any person causing nuisance" or restricting usage to mere right of passage (Cuthbert \& McKinnel, 200I).

Economised urban infrastructures, surrogating and supplanting the public ones, constitute systems of institutions that interfere with the physical and social spatialities of the commons of the traditional city, upsetting their distribution, displacing their spatial practices, and perturbing the perception of their networks. These disruptions originate from competitive and dominant instead of complementary and collaborative objectives that tend to opportunistically intercept and exploit systemic opportunities rather than contribute to expand them. As sets of engrafted prosthetic organs - constituted by commons where indeterminacy is substituted with over-determination, such as festivalisation of marketplaces and choreographization of mall atriums - they redefine centralities, deterritorialise consolidated geographies and reterritorialize within 
controlled enclosures. These enclosures have been described as all-inclusive and semiautonomous mini-cities with enclavic character that exacerbate the on-going segmentation and polarisation of the wider city (Shane, 20I I: 329ss). Their antagonism to the traditional open systems is manifested not only in their introversion, but also in the seamless transitional space that interconnects them. This space is made of armatures, such as urban freeways and subways, that have high capacity, social neutrality, and weld the scattered enclosures into seamless city-wide rhizomatic assemblages

Specific to the enclavic assemblages is the strong transductional capacity (i.e., the ability to use information to iteratively transform perception and usage of space) that makes them a peculiar kind of Foucauldian heterotopia. The extension and complexity of their systems transform interiors into exteriors, peripheries in to centres, making their introverted, displaced and disjoined places sites of normalised and habitual experience. Their all-inclusiveness reproduces, as an allegoric mirroring, the "real" centres of the city that they supplant: by normalising both discontinuity and simulative reproduction, they contest, suspend, neutralise or invert the set of relations that they simultaneously designate (Foucault, 1995, 2008 [1982]).

Importantly, these assemblages produce sequences of conflicting juxtapositions that both formally and semantically frame the displaced reproductions with the most obvious representational and functional reference: the ideal city. As described by Gernot Bohme (2012: 258), imposing meta-narratives of "cityness" evokes meanings, experiences and patterns of what is "other" to them. Overarching structures of coordinated typomorphological reproductions of stereotypical representations mirror "past or distant public places" (Goss 1993: 19). Pseudo-commons, such as arcaded streets, fountain squares, local market halls, establish the backbone of their urban structure with imitative layouts, massing, material connotations and naming. Places are often named to proclaim their virtual publicness as "civic plazas," "town squares" (Manfredini, 20 I7); occasionally, ostenting bold explicit themes, such as the Venetia, Parisian and Londoner flagship Sands mega-resort cluster in Macau. The corollary function of these "fixed scenes" is to set the tone for chains of sub-otherness of shopping and entertainment to be nestled "ad infinitum."

\section{From ambivalence to contradiction: The illusionary compensation of "othernesses" and the abstractive differentialism of simulacra}

Among the numerous theoretical interpretations that analyse the efficaciousness of the hyper-spatialities of these heterotopic places in establishing themselves as prime social catalysts in our cities, significant ones focus on their capacity to constitute apparatuses that lure their users by producing illusionary environments. Particularly useful, to critically address the evolution of this discussion on the age of pervaded augmented representation, are the specific contributions to the discourse on illusion and simulation in complex relational systems of Michel Foucault and the duo Deleuze and Guattari. Elaborating the concept of heterotopia, Foucault delineates a systematic description of its constitutive principles, including one that concerns its function to relate the real and the imaginary (De Cauter \& Dehaene, 2008b: 25, 27). This function is to regulate the relations between the heterotopic place and "the rest," by embodying the non-real 
spaces of utopia and making it the vehicle to access the wonder - the most precious treasures concealed in the "gardens" of the world (Foucault, 2008 [1967]: 22). As means to achieve this, Foucault identifies a range between two extreme poles: illusion and compensation. Compensation is delivered by places that deploy an abstracted reality "as perfect, as meticulous, as well arranged as ours is disorderly, ill construed and sketchy" (Foucault, 2008 [1967]: 21; Shane, 2005: 37, 42). Illusion is afforded with very special mechanisms that, whilst providing conditions to satisfy desires, deploy the crucial awareness agency of enabling the subject to understand the illusive nature of the "real" and the supressing nature of the superstructures in "the interior of which human life is enclosed and partitioned" (Foucault, 1995: 2I).

The urban enclavic transductional assemblages adopt this functional principle in a very peculiar way. They conflate the two extreme delivery means of the functional principle by packaging illusion and compensation in a simultaneous, yet disjoined, conveyance. On the one hand, digitally enhanced transductive simulation is used to deploy compensatory conditions that make real or virtually accessible idealised paradigms of civic order and social harmony; on the other hand, illusion is employed to offer semi-fictional conditions that embody desired realities "supposed to lift us out of the mire of our everyday lives and [lead us] into the sacred spaces of ritualized pleasures" (Zukin, 1995: I). Their awareness agency unveils the ineffectuality of these mirrored pseudo-cities exposing the mechanisms of control and deception that leave the forces triggered by desire hindered and unable to unfold their "greatest reserve of imagination" (Foucault, 1995: 22). The consolatory and relieving compensation is crushed by the limitations of unilateral governance's policies (e.g., rigid codes of conduct, opening hours and location of augmented reality points of interest [POI]) and procedures (e.g., panoptical and integrated physical and digital surveillance methods). The illusory experience unveils the superstructuralism of the systems manifesting the untimeliness and non-appropriateness of the reified practices and rites (e.g., the minimal relationship-building capacity of McDonaldised coffee shop and parochial spaces created with augmented reality games). A paradox presented by these augmented and simulative heterotopias is their growth in popularity in spite of their manifested deviousness. Their governing bodies attract people by exploiting the power of desire to attract people with the production of utopian embodiments that, equivalent to the Foucauldian greatest reserve of imagination: the ships of the colonial times (Foucault, 1995: 22) that made accessible the most precious treasures of the age. Yet, they develop a contradiction between the instrumental dominating ends and the free play of desire. This results in fallacious simulations whose mirroring methods enact a form of productive repetition that intensifies autonomous associative processes of spatial reappropriation. Relevant evidence of this paradox is found in the social construct autonomously generated by individuals and communities with the digitally enabled creation of materials, links and spatialities. An example is the disproportionately high amount and quality of place-based interactions and spatial representations produced in these places on image-based, locative digital social media (Manfredini, 2019; Manfredini \& Rieger, 2017; Tian et al., 2017).

The theory developed by Deleuze (1994), in his seminal discussion on repetition, entails a crucial aspect of simulation that illuminates this representational paradox. Deleuze identifies repetition as a subversive force of differentiation that counteracts the 
enforced suppressions of imaginary capacity. It institutes instances of individuation, rather than creating homologating, inauthentic and impure copies. It actualises ideas and reconstitutes or re-creates a type of spatial instance that does not replace reality, but rather produces reality by appropriating it through a "despotic overcoding" (Deleuze, 1994: 38, 67; Deleuze \& Guattari, 2000: 210; D. Smith, 2006). The overcoding results from an independent and creative interpretation of what is repeated through a fabulatory process that uses “'redundancy' or 'excess' to reassociate and open to infinite new interpretations elements that have been disjoined for dominating and controlling purposes" (Deleuze \& Guattari, 1987: I14). The recognition of simulation as a productive force constituted by the differential nature of repetition that opposes homogenising forces reflects what Lefebvre identifies as "presence." Presence is a creative and inventive condition. Its manifestation emerges when repetition produces difference through the encounter of the event in the dramatic becoming of the haecceity and opposes what effaces the "immediate" and interrupts interaction - the "present" as cunning repetition conformed to a standard (Lefebvre, 2004 [1992]: 7, 39, 47). This opposition is the same for "differential" to "abstract" spaces (I99I [1974]: 352-400), where, by simulating presence, hegemonic powers erase differences and surrogate relations with derivatives that disdain life to implement oppressive and repressive strategies of control, homologation, hierarchic order and segregation.

\section{Abstractive forces: Simulation and desire control}

This and the following section discuss the paradoxes emerging in the conflictual relations between abstract and differential spaces, exploring what fuels the simulatory spatial production of the enclavic transductional assemblages. The interpretation of the forces behind the advanced transductive simulations, which transform the commercial abstract spaces of the heterotopic assemblages in the age of experience economy, is guided by the theories of Deleuze (and Guattari) on the internal dynamics of the conflicting yet consubstantial oppositions that make individuals invest in social systems that constantly repress them (D. Smith, 2007: 74). This enables us to read commercedriven complexes as apparatuses created to elaborate and fulfil customers' desires to consumerism ends. It unveils how expressed, latent and induced drives and impulses are captured with simulated realities that deflect and commodify them through surrogate instances. "Empty bodies without organs" (Deleuze \& Guattari, 2000: 9-17) are produced by overpowering organisations to homogenise and disestablish spontaneous organisational life, creating a realm of scripted relationality with manufactured ecologies that take the place of indigenous ones. They tease and betray drivers of desires by obliterating the fundamental oppositions on which they rely. The disestablishment of dyads such as real/represented, authentic/counterfeit, and homogeneous/fractured make it possible to re-morph, de-associate, uncouple and "crudely" cobble back together (Lefebvre, 199I [1974]: 309, 352-356, 636) desires and needs of individuals to match them to lacking elements of social formations cunningly designed and imposed on them (D. Smith, 2007: 73-75).

In these complexes, to prevent the potentially disruptive effects of autonomous differential forces, simulation is implemented with abstractive routines of controlled and automated repetition (Lefebvre, 2004 [1192]: 40, I99। [1974]: 38-39, 352-356, 636; 
Deleuze \& Guattari, 1987: 2II-2I2). The critique on these routinary, simulative processes has been extensive and has produced comprehensive descriptions of the surreptitious ways in which desire is exploited by established economic powers to influence and control users' behaviours and choices. Appraisals of the specific methods that cope with transformational experience economy imperatives and their "participatory" approach to choice, creativity, and self-realisation, include the discourse evolved from the Debordian critique of the strategies and effects of the "super-added information" in The Society of the Spectacle (1983). Important elaborations address the novel forms in which publics are subjected to the "strangling seduction" of the deceptive and consolatory commodity fetishism of the seamless global "junkspace" (Koolhaas, 2002: 176). The efficacious use of the power of desire is described as a complement to the enhancement of socio-spatial fragmentation, compartmentalisation, and segregation.

In contemporary cities, the diffuse scarcity of civicness (i.e., lack in centrality and differentiation, communal and communing spatialities [urban commons and amenities], and identity and referentiality), particularly acute in has favoured the deployment of these apparatuses of simulative actualisations in full-scale heterotopic collective social spaces, such as integrated shopping malls with entertainment, cultural, employment and residential components. The creation of these surrogative "live, work and play" conflations includes the deployment of the state-of-the-art digital technologies that transform the core "abstractive" apparatuses of the modern malls into ultra-virtualising into multiscalar hypermediated relational assemblages.

Technological advances enable to create multilevel apparatuses of resonances where abstraction and differentiation are do not differ because of the rigidness or suppleness segmentarity, but for the openness or closure of their systems. Reproducibility, molarity, bounding, rigidness, discreteness and continuous induced mutation, their key features, as listed by Deleuze and Guattari (1987: 210-13), are dissimulated and proposed as their "differential" opposites: individuation, molecularity, openness, suppleness, and continuous produced mutation.

Individuation and molecularity are dissimulated with the introduction into the consumption systems of front-line participatory production practices. Personalised engagement using artificial intelligence, predictive analysis, and the Internet of Things, activates various forms of independent labour and creativity of the consumer (e.g., digital shopping assistant services that allow the customer to order multiple meals from different restaurants within the same mall, select dishes and their ingredients, and set the preparation time according to desired collection routine). The dissimulation also includes advanced individual profiling of expressed and monitored preferences, and personalised emotional labour. These services, whilst substantially improving the customer's experience, choice and effectiveness, produce radical homogenisation that affords major competitive advantages to large international corporations over small local agencies (e.g., requiring major investments in setup and maintenance of services subject to steady innovation involving big data analytics, enterprise cloud and cyber security).

Openness is provided by participatory digital spatial transduction that enables individuals to access multiple spatial and social sub-realms and engages them in inexhaustible numbers and combinations (e.g., providing multidimensional links to the multitude of 
actants that visit the centres). Openness is also combined with suppleness in the use of transduction to grant personal "tunability" of places and atmospheres by making the experiential multiple layers modifiable and adjustable to individual needs (Coyne, 2010). There, the plasticity of their environments is finely orchestrated to manipulate behaviours and coordinate the kaleidoscopic conflation of goods and services for hyperconsumption (e.g., cunningly placing POls in a mall courtyard to encamp parochial realms of AR games, such as Pokémon Go's “stops" and "gyms").

The combination of participatory consumption, transduction and tunability in conditions of improved experientiality and relentless eventfulness affords an internal incremental production, becoming and continuous mutation. This expands networkability by providing infrastructure and services to assist multimodal access to and multidimensional communication with a widening multitude of people and things both compresent and remote, spatially and chronologically (e.g., the intense social campaigns of mall operators to improve experience and support the expansion of digital communities on social media, such as Facebook, Twitter, Instagram, and Pinterest). The increments in social networks, particularly acute in digital media, are strongly supported, monitored and controlled by the hegemonic organisations, since, more and more, participatory processes occupy a central role in marketing strategies.

Overall, artfully compounded deceiving and simulation tactics unfold systems of overabundant social, material and cognitive loops with apparent self-sufficient character. They capture desire with relationality-forming mechanisms that entrap it in closed loops centred on commodities and embed it in a hybrid experience of the lifeworld that involves socialisation (Bäckström, 20 I I; Massicotte et al, 20I I) play and wellbeing (e.g., the augmented reality games capacity to redefine technological and cultural practices [Hjorth \& Richardson, 20I7] and stimulate physical activity [LeBlanc \& Chaput, 20I7]). This is achieved by providing pre-constituted locked assemblages of disparate elements, such as scripted events that spark controlled social play between unacquainted people, or making available predetermined and programmed assembling devices, such as activating networking POls of locative digital social media.

To afford imperviousness to these mechanisms, their domains are endowed with close, self-referential systems that guarantee control and prevent the development of autonomous forces that enable genuine engagement in open, productive and creative acts. Within these loops, simulation, paraphrasing Daniel Smith's (2006) comments on the concept of simulacrum, renders indiscernible and internalises the difference between heterotopia and the city itself - "the rest," the left over - "thereby scrambling the selection and perverting the judgment" (102).

\section{Conclusion: Resilient commons, differential forces and the liberating power of desire}

The creative and productive power of desire triggers differential forces that express the resilience embedded in the autonomous socio-spatial assemblages. Constituting open systems with molecular associations and incremental production in continuous evolution that thrive in enhanced places of participatory consumption, transduction and tunability, it introduces disruptive challenges in the closed systems of the illusionary 
heterotopias and develops autonomous forms of socio-spatial relationality and territorialisation.

In their discussion on territories and networks, Deleuze and Guattari (1987) state that the power of desire operates in a dual relational process of a primarily social kind, where connections and productive associations are simultaneously assembling and being assembled $(212,399)$. Similar to the Lefebvrian "production of space," the ambivalence of desire consists of its capacity to produce associations whilst producing its desiring subject. Its autonomy and independence towards differential production contrasts the closed circles of redundancy of the abstractive spatialities of the instituted powers. As Lefebvre (199I [1974]) puts it, referencing Nietzsche's "Grand Desire" - desire strives "to overcome divisions - divisions between work and product, between repetitive and differential, or between needs and desires" and liberate conflicts and differences that are therewith materialised (392-393).

Desire penetrates in abstractive, spatially transductive and tunable commercial assemblages through the gap opened by their false alliance with participatory consumption. It introduces its core differential agency in the progressively autonomous dynamics of the new modes of production of the collaborative economy that the abstractive simulation process intends to mirror, yet cannot dominate. In a resilient development, it generates what Lefebvre (199I [1974]) calls a "transitional state" where growing internal conflicts cannot last indefinitely (374). From the perspective of the integral sustainability of Deleuze and Guattari, the contradiction between, on the one hand, the segmentation and compartmentalisation of the ever-expanding simulative mechanisms controlled by the instituted powers and, on the other hand, the steadily growing autonomous production of emancipatory associative and experimentally creative desiring machines, becomes increasing untenable.

Examples of the crisis of these conflicts in everyday life can be found in the digital sphere; whilst the abstractive forces steadily enhance the performance of their digital media infrastructure to implement their core hyper-consumerist strategies, reinforce their socio-spatial hegemony and cope with the democratisation imperative of the sharing economy, the very same infrastructure supports the growth of the autonomous aggregations and associations that are a key characteristic of the latter. Two relevant paradoxical cases concerning non-compliant digital media usage are: a) the concurrent vetoing of taking photographs and videos in shopping malls - as warned at each of their entry points - and the contrasting support given to interaction on image-based social media services; and b) the development of "online to offline" retail systems - that merge traditional and online marketing of the same company - and openly accept the brazen purchase practices of customers who, straight after trying and selecting the goods, proceed to buy them from cheaper online competitors.

The difficulty in controlling the freeing agency of simulation supports the development of relational processes that permanently increase the number of "deviant" associations and connections. They range from being wholly antagonist to accomplices in deflecting their own desires, yet both open paths towards important reappropriation of creative and cultural experiences (Harvey, 2012: II-I4; Miles, 20I2; Miles \& Miles, 2004; Rifkin, 2000; Susilo \& De Meulder, 20 8; Styhre \& Hagberg, 20I3; Witkin, 2003: 3-5; Zukin, 1995). These processes, bolstered by the subversive agency of the productive desire, strengthen the capacity and power of autonomous actants to establish autonomous 
association that deterritorialise and reterritorialise the ever-expanding realms of augmented transductional contextualisation. Haecceity-driven becomings have already shown phenomena of mall "cannibalisation" (Susilo \& De Meulder, 20I8: 149) that transvaluate the context, "letting its parts fly free to connect in diverse ways" (Petrescu, 2005: 45). Guaranteeing the exercise of theright to difference, these assembled/assembling heterotopias efficaciously reactivate the lived temporality of "the rest" - what has been abstracted, excluded and marginalised. By widening the fractures of the closed systems, the play of the commodity spectacle and the fabricated metanarratives of control are unmasked, unveiling the way desire is subjugated by control mechanisms that manipulate the flow of interaction and the formation of associations. The repression of relational needs loses its effectiveness, destabilises the gained complicity of the user in the production of the consumerist spectacle of goods, and unlocks the productive production of the loops of redundancy or "excess." The metamorphic networks and the multiple "lines of flight" granted by the democratisation of the simulative digital atmosphere of transduction set free unrestrained simulative chains of spatial production. These, in turn, pioneer forms of antagonistic reappropriations and re-association of individuals and spatialities, responding to the demands of productive desire to transform the simulated common world into an actual one. The reintroduction of individual autonomy and independence supports novel collective forms of a political project for the reinstitution of the right to the city and right to difference, which includes the resistance against rigid segmentation, dispossession, segregation and abstraction of the "civic." New civic institutional systems, counter-hegemonic organisation and commoning forces operate a restructuring of the deterritorialised commons, building "alliances and linkages across space in such a way as to mitigate or challenge the hegemonic dynamics of capitalist accumulation that dominate the historical geography of social life" (Harvey, 1989: 16) for the affirmation of a "space of the dream" (Lefebvre, 199I [1974]: 35) with supple commons where desire has full play to sustain a robust and integral wellbeing.

\section{Acknowledgement}

This research is funded through the New Zealand's Ministry of Business, Innovation and Employment of programme Building Better Homes, Towns and Cities, National Science Challenge contestable fund - Give Us Space project.

\section{References}

Anderson, B., \& McFarlane, C. (Eds.). (20I I). Assemblage and geography. Area, 43, I24-64. Arendt, H. (1958). The human condition. Chicago: University of Chicago.

Atkinson, R. (2003). Domestication by cappuccino or a revenge on urban space? Control and empowerment in the management of public spaces. Urban Studies, 40(9), I829-I843.

Bäckström, K. (20l I), "Shopping as leisure: an exploration of manifoldness and dynamics in consumers shopping experiences", Journal of Retailing \& Consumer Services, I8(3), 200209. 
Banerjee, T. (200I). The future of public space: Beyond invented streets and reinvented places. Journal of the American Planning Association, 67(1), 9-24.

Benhabib, S. (2000). The reluctant modernism of Hannah Arendt. Thousand Oaks: Sage.

Bohme, G. (20I2). Flanieren in der Postmoderne. Die Shopping Mall als ästhetischer Raum. Der Architekt, 2, 28-32.

Bollier, D. (2002), Silent Theft: The Private Plunder of Our Common Wealth, New York: Routledge.

Borch, C., \& Kornberger, M. (Eds.). (20I5). Urban commons: Rethinking the city. Abingdon, Oxon: Routledge.

Brenner, N., \& Theodore, N. (2005). Neoliberalism and the urban condition. City, 9(I), I0I-I07.

Brighenti, A. M. (20।4). Mobilizing territories, territorializing mobilities. Sociologica, I.

Calhoun, C. (1992). Introduction: Habermas and the public sphere, in C. Calhoun (Ed.), Habermas and the public sphere. Studies in contemporary German social thought. Cambridge, MA: MIT Press, I-50.

Connolly, W. (2005). The evangelical-capitalist resonance machine. Political Theory, 33(6), 869886.

Coyne, R. (2010). The tuning of place: Sociable spaces and pervasive digital media. Cambridge, MA: MIT Press.

Cuthbert, A., \& McKinnel, K. (200I). Public domain, private interest: Social space in Hong Kong, in P. Miao (Ed.), Public places in Asia Pacific cities. Dordrecht, Netherlands: Kluwer Academic Publishers, $|9|-2 \mid I$.

Davis, M. (1990). City of quartz: Excavating the future in Los Angeles. New York: Verso.

Dawson, A. (2010). Introduction: New enclosures. New Formations, 69, 8-22.

Debord, G. (1983). Society of the spectacle. Detroit: Black \& Red.

Dehaene M., \& De Cauter, L. (2008a). Heterotopia: A postcivil society, in M. Dehaene \& L. De Cauter (Eds.), Heterotopia and the city: Public space in a postcivil society. Abingdon, Oxon: Routledge, 3-9.

Dehaene M., \& De Cauter, L. (2008b). Notes, in M. Dehaene \& L. De Cauter (Eds.), in Heterotopia and the city: Public space in a postcivil society. Abingdon, Oxon: Routledge, 22-29.

Deleuze, G. (1994). Difference and repetition, New York: Columbia University Press.

Deleuze, G., \& Guattari, F. (1987). A thousand plateaus. Minneapolis: University of Minnesota Press.

Deleuze G., \& Guattari, F. (2000) Anti-Oedipus: Capitalism and schizophrenia, London: Athlone.

Doherty, J., Busch-Geertsema, V., Karpuskiene, V., Korhonen, J., O'Sullivan, E., Sahlin, I., Tosi, A., Petrillo, A., \& Julia W. (2008). Homelessness and exclusion: Regulating public space in European cities. Surveillance and Inequality, 5(3), 290-3I4.

Farías, I., \& Bender, T. (Eds) (2010). Urban assemblages: How actor-network theory changes urban studies, London: Routledge.

Firat, A. F., \& Venkatesh, A. (1995). Liberatory postmodernism and the reenchantment of consumption. Journal of Consumer Research, 22(3), 239-267.

Flusty, S. (1997). Building paranoia, in N. Ellin (Ed.), Architecture of fear. New York: Princeton Architectural Press, 47-60.

Foucault, M. (1995). Discipline and punish: The birth of the prison, New York: Vintage Books.

Foucault, M. (2008 [1967]). Of other spaces, in M. Dehaene and L. De Cauter (Eds.), in Heterotopia and the city: Public space in a postcivil society. Abingdon, Oxon: Routledge, 13-29.

194 | The Journal of Public Space, 4(2), 2019 | ISSN 2206-9658

City Space Architecture / UN-Habitat 
Foucault, M. (2008 [1982]). Space, Knowledge, And Power. Interview conducted by Paul Rabinow, in J (Ed.), Power, Essential Works of Foucault (1954-1984), Vol. 3. New York: New Press, 349-364.

Fuller, A., Hickey, M., \& Bunnell, T. (20/2). Asian urbanisms and mallness in Recording the Future (RtF) (183). Singapore: Asia Research Institute.

Garnett, N. S. (2012). Managing the urban commons. University of Pennsylvania Law Review, I60, 1995-2027.

Goonewardena, K., Kipfer, S., Milgrom, R., \& Schmid, C. (Eds.). (2008). Space, difference, everyday life: Henri Lefebvre and radical politics. London: Routledge.

Goss, J. (1993). The "magic of the mall": An analysis of form, function, and meaning in the contemporary retail built environment. Annals of the Association of American Geographers, 83(I), 18-47.

Hardt, M. (2010) The common in communism. Rethinking Marxism, 22(3), 346-356.

Hardt, M., \& Negri, A. (2009). Commonwealth. Cambridge, MA: Belknap Press of Harvard University.

Harvey, D. (1989). From managerialism to entrepreneurialism: The transformation in urban governance in late capitalism. Geografiska Annaler. Series B, Human Geography, 7I (I), 3-I7.

Harvey, D. (2003). The new imperialism. New York: University Press.

Harvey, D. (2008). The right to the city. New Left Review, 53, 23-40.

Harvey, D. (201 I). The future of the commons. Radical History Review, 109.

Harvey, D. (20I2). Rebel cities: From the right to the city to the urban revolution. New York: Verso Books.

Hjorth, L., \& Richardson, I. (20I7). Pokémon GO: Mobile media play, place-making, and the digital wayfarer, Mobile Media \& Communication, 5(I), 3-I4.

Hodkinson, S. (20I2). The new urban enclosures. City, I6(5), 500-5I8.

Holston, J. (2009). Insurgent citizenship: Disjunctions of democracy and modernity in Brazil. Princeton: Princeton University Press.

Kärrholm, M. (2012). Retailising space: Architecture, retail and the territorialisation of public space. Surrey, England: Ashgate.

Koolhaas, R. (2002). Junkspace. Obsolescence, 100, 175-190.

Latour, B. ( 1999$)$. On recalling ANT, in Law J. \& Hassard J. (Eds.), Actor-network theory and after. Oxford: Blackwell, 15-25.

Latour, B. (2005). Reassembling the social: An introduction to actor-network-theory. Oxford: Oxford University Press.

Law, I. (2009). Actor network theory and material semiotics, in B. S. Turner (Ed.), The new Blackwell companion to social theory. Malden, MA: Blackwell, I4I-I58.

LeBlanc, A., \& Chaput, J.P. (2017). Pokémon Go: A game changer for the physical inactivity crisis? Preventive Medicine, I0I, 235-237.

Lee, S., \& Webster, C. (2006). Enclosure of the urban commons. Geolournal, 66, 27-42.

Lefebvre, H. (I99I [1947]). The critique of everyday life, Volume I (J. Moore trans.). London: Verso.

Lefebvre, H. (199I [1974]). The production of space. Oxford: Blackwell.

Lefebvre, H. (1996). Writings on cities. Cambridge, MA: Blackwell.

Lefebvre, H. (2003 [1970]). The urban revolution (R. Bononno, trans.). Minneapolis: University of Minnesota Press. 
Lefebvre, H. (2004 [1992]). Rhythmanalysis, space, time and everyday life. London: Continuum. Loukaitou-Sideris, A. (1993). Privatisation of public open space: The Los Angeles experience. The Town Planning Review, 64(2), 139-167.

Low, S. (2006). How private interests take over public space: Zoning, taxes, and incorporation of gated communities, in S. Low \& N. Smith (Eds), Politics of public space. New York: Routledge, $8 \mathrm{I}-104$.

Low, S., \& Smith, N. (Eds.). (2006). Politics of public space. New York: Routledge.

Manfredini, M. (2017). The augmented meta-public space: Interpreting emerging transductive territories in enhanced centres of consumption. The Journal of Public Space, 2(3), III-I28.

Manfredini, M. (2019). Give us space: Improving community well-being by enhancing performance and communication of semi-public space in the evolving public realm. Retrieved from https://www.drh.nz/give-us-space/

Manfredini, M., \& Jenner, R. (20I5). The virtual public thing: De-re-territorialisations of public space through shopping in Auckland's urban space. Interstices: Journal of Architecture and Related Arts, 16, 70-81.

Manfredini, M., \& Rieger, U. (2017). Dynamics of territorial production in situated and community projects, in D. Brown, M. Manfredini, P. McPherson, A. Pretty, U. Rieger, \& M. Southcombe (Eds.), Crossing boundaries: Reflections on applied collaborative architectural research. Siracusa, Italy: Lettera Ventidue, I59-166.

Manfredini, M., \& Ta, A. N. (2016). Co-creative urbanism: The production of plural evolutionary spatialities through conflicts and complicities between public and private in the streets of Hanoi, Vietnam. Joelho, Journal of Architectural Culture, 7, I32-I55.

Manfredini, M., \& Ta, A. N. (20I7). The production of pluralistic spatialities: The persistence of counter-space territories in the streets of Hanoi, Vietnam, in R. Galdini, A. Marata \& M. Spada (Eds.), Creative cities: Public space and everyday places. Rome: CNAPPC, 373-38I.

Manfredini, M., Xin, T, Jenner, R., \& Besgen, A. (2017). Transductive urbanism: A method for the analysis of the relational infrastructure of malled metropolitan centres in Auckland, New Zealand. Athens Journal of Architecture, 3(4), 4I I-440.

Manfredini, M., Zamani G., F., \& Leardini, P. (2017). Instances of emerging agonistic spatialities in the contemporary city: The production of differential geographies in the public space of Istanbul. Asian Journal of Humanities and Social Studies, 5(5), 28I-29I.

Massey, D. (2007). World city. Cambridge, England: Polity.

Massicotte, M. C., Michon, R., Chebat, J. C., Joseph Sirgy, M., \& Borges, A. (20II). Effects of mall atmosphere on mall evaluation: Teenage versus adult shoppers. Journal of Retailing and Consumer Services, 18(I), 74-80.

McFarlane, C. (20II). Learning the city: Knowledge and translocal assemblage. Oxford: WileyBlackwell.

McQuire, S. (2008). The media city: Media, architecture and urban space. Los Angeles: Sage.

Merriman, P. (2012). Human geography without time-space. Transactions of the Institute of British Geographers, 37(1), 13-27.

Miles, S. (20I0). Spaces for consumption: Pleasure and placelessness in the post-industrial city. Los Angeles: Sage.

Miles, S. (2012). The neoliberal city and the pro-active complicity of the citizen consumer. lournal of Consumer Culture, 12(2), 216-230.

Miles, S., \& Miles, M. (2004). Consuming cities. New York: Palgrave Macmillan.

196 | The Journal of Public Space, 4(2), 2019 | ISSN 2206-9658

City Space Architecture / UN-Habitat 
Minton, A. (2012). Ground control: Fear and happiness in the twenty-first century city. London: Penguin.

Mitchell, D. (1995). The end of public space? People's Park, definitions of the public, and democracy. Annals of the Association of American Geographers, 85, 108-I33.

Mitchell, D. (2003). The right to the city: Social justice and the fight for public space. New York: Guilford.

Mommaas, H. (2004) Cultural clusters and the post-industrial city: Towards the remapping of urban cultural policy. Urban Studies, 4I(3), 507-532.

Mouffe, C. (1999). Deliberative democracy or agonistic pluralism? Social Research, 66(3), 745758.

Mouffe, C. (2008). Public spaces and democratic politics. In J. Boomgaard (Ed), Highrise-common ground. Art and the Amsterdam Zuidas area, Amsterdam: Valiz, I35-I56.

Murdoch, J. (1998). The spaces of actor-network theory. Geoforum, 29(4), 357-374.

Park, R. (1967). On social control and collective behavior. Chicago: University of Chicago Press.

Parr, A. (2015) Urban debt, neoliberalism and the politics of the commons. Theory, Culture \& Society, 32(3), 69-9l.

Petrescu, D. (2005). Losing control, keeping desire, in P. Blundell Jones, D. Petrescu, \& J. Till (Eds.), Architecture and participation, Abingdon, Oxon: Taylor \& Francis, 43-6I.

Purcell, M. (2002). Excavating Lefebvre: The right to the city and its urban politics of the inhabitant. Geojournal, 58(2-3), 99-108.

Purcell, M. (2014). Possible worlds: Henri Lefebvre and the Right to the City. Journal of Urban Affairs, 36(I), | I4I-I54.

Rifkin, J. (2000). The age of access: The new culture of hypercapitalism, where all of life is a paid-for experience. New York: Tarcher/Putnam.

Sennett, R. (1977). The fall of public man. New York: Knopf.

Sennett, R. (2008). Reflections on the public realm, in G. Bridge \& S. Watson (Eds.), A companion to the city. Chichester: Wiley-Blackwell, 390-397.

Sennett, R. (2018). Building and Dwelling: Ethics for the City. New York: Farrar, Straus and Giroux. Shepherd, R. (2002). Commodification, culture and tourism. Tourist Studies, 2(2), I83-20I.

Shane, D. G. (2005). Recombinant urbanism: Conceptual modeling in architecture, urban design, and city theory. London: Wiley-Academy.

Shane, D. G. (20II). Urban design since 1945: A global perspective. London: Wiley-Academy.

Smith, D. (2006). The concept of the simulacrum: Deleuze and the overturning of Platonism. Continental Philosophy Review, 38(I-2), 89-123.

Smith, D. (2007). Deleuze and the question of desire: Toward an immanent theory of ethics, Parrhesia, 2, 66-78.

Smith, N. (2002). New globalism, New Urbanism: Gentrification as global urban strategy. Antipode, 34(3), 427-450.

Soja, E. (1989). Postmodern Geographies: The reassertion of space in critical social theory. London: Verso Press.

Soja, E. (2000). Postmetropolis: Critical studies of cities and regions. Oxford: Blackwell.

Soja, E. (2010). Seeking spatial justice. Minneapolis: University of Minnesota Press.

Sorkin, M. (Ed.). ( 1992). Variations on a theme park: The new American city and the end of public space, New York: Hill and Wang.

Stanek, L. (20I I). Henri Lefebvre on space. Minneapolis: University of Minnesota Press. 
Steel, M., \& Symes, M. (2005). The privatisation of public space? The American experience of business improvement districts and their relationship to local governance. Local Government Studies, 3I(3), 32I-334.

Styhre, A., \& Hagberg, J. (2013). The production of social space: Shopping malls as relational and transductive spaces. Journal of Engineering, Design and Technology, II (3), 354-374.

Susilo, C., \& De Meulder, B. (20I8). The Boulevard Commercial Project of Manado, Indonesia: Trickled-down globalization versus a catalyzed super local, in J. Gosseye \& T. Avermaete (Eds.), Acculturating the shopping centre. London: Routledge, 147-163.

Susser, I., \& Tonnelat, S. (20I3). Transformative cities: The three urban commons. Focaal, 66, $105-121$.

United Nations General Assembly (2016). New Urban Agenda, (A/RES/7I/256), New York: United Nations.

Villa, D. (1992). Postmodernism and the public sphere. American Political Science Review, 86(3), $7|2-72|$.

Witkin, R. W. (2003). Adorno on popular culture. London: Routledge.

Xin, T., Manfredini, M., Zamani, F., Xu, L., Li, Y., \& Wang T. (2018). Public life in megamalls. Chinese \& Overseas Architecture, 4, I8-23.

Zukin, S. (199I). Landscapes of power: From Detroit to Disney World, Berkeley: University of California Press.

Zukin, S. (1995). The cultures of cities. Oxford: Blackwell. 